\title{
Detection and characterisation of aluminium-containing nanoparticles in Chinese noodles by single particle ICP-MS
}

\author{
Löschner, Katrin; Correia, Manuel; López Chaves, Carlos; Rokkjær, Inge; Sloth, Jens Jørgen
}

Published in:

Food Additives \& Contaminants: Part A - Chemistry, Analysis, Control, Exposure \& Risk Assessment

Link to article, DOI:

$10.1080 / 19440049.2017 .1382728$

Publication date:

2018

Document Version

Peer reviewed version

Link back to DTU Orbit

Citation $(A P A)$ :

Löschner, K., Correia, M., López Chaves, C., Rokkjær, I., \& Sloth, J. J. (2018). Detection and characterisation of aluminium-containing nanoparticles in Chinese noodles by single particle ICP-MS. Food Additives \& Contaminants: Part A - Chemistry, Analysis, Control, Exposure \& Risk Assessment, 35(1), 86-93. https://doi.org/10.1080/19440049.2017.1382728

\section{General rights}

Copyright and moral rights for the publications made accessible in the public portal are retained by the authors and/or other copyright owners and it is a condition of accessing publications that users recognise and abide by the legal requirements associated with these rights.

- Users may download and print one copy of any publication from the public portal for the purpose of private study or research.

- You may not further distribute the material or use it for any profit-making activity or commercial gain

- You may freely distribute the URL identifying the publication in the public portal 
Containitis

\author{
Food Additives \& Contaminants: Part A
}

\title{
Detection and characterization of aluminium- containing nanoparticles in Chinese noodles by single particle ICP-MS
}

\author{
Katrin Loeschner, Manuel Correia, Carlos López Chaves, Inge Rokkjær \& Jens \\ J. Sloth
}

To cite this article: Katrin Loeschner, Manuel Correia, Carlos López Chaves, Inge Rokkjær \& Jens J. Sloth (2017): Detection and characterization of aluminium-containing nanoparticles in Chinese noodles by single particle ICP-MS, Food Additives \& Contaminants: Part A, DOI: 10.1080/19440049.2017.1382728

To link to this article: http://dx.doi.org/10.1080/19440049.2017.1382728

Accepted author version posted online: 21

Sep 2017.

Submit your article to this journal

LII Article views: 8

Q View related articles $๘$

View Crossmark data $\nearrow$ 


\section{Detection and characterization of aluminium-containing nanoparticles in Chinese noodles by single particle ICP-MS}

Katrin Loeschner ${ }^{1}$, Manuel Correia ${ }^{1}$, Carlos López Chaves ${ }^{2}$, Inge Rokkjær ${ }^{3}$, Jens J. Sloth $^{1}$

${ }^{1}$ Division of Food Technology, National Food Institute, Technical University of Denmark, Kemitorvet 201, DK-2800 Kgs. Lyngby, Denmark

${ }^{2}$ Biomedical Research Centre, iMUDyS, Department of Physiology, Faculty of Pharmacy, University of Granada, Campus Cartuja, 18071, Granada, Spain

${ }^{3}$ Danish Veterinary and Food Administration, Chemical Laboratory Aarhus, Sønderskovvej 5, DK-8520 Lystrup, Denmark

ORCiD:

Katrin Loeschner: orcid.org/0000-0003-1741-8406

Carlos López Chaves: orcid.org/0000-0002-9249-5244

Jens J. Sloth: orcid.org/0000-0002-3636-8769

Corresponding author:

Katrin Loeschner

Phone: +4535887029

Fax: +4535887448

Email:kals@food.dtu.dk 


\title{
Detection and characterization of aluminium-containing nanoparticles in Chinese noodles by single particle ICP-MS
}

\begin{abstract}
This study investigated Chinese noodles for the presence of aluminiumcontaining nanoparticles by using inductively coupled plasma mass spectrometry in single particle mode (spICP-MS) after enzymatic digestion by $\alpha$-amylase. The aluminium concentrations in the noodle samples, determined by conventional ICP-MS without or with the use of hydrofluoric acid for digestion, were $5.4 \pm 1.9$ $\mu \mathrm{g} / \mathrm{g}$ and $10.1 \pm 2.2 \mu \mathrm{g} / \mathrm{g}(\mathrm{N}=21)$, respectively. Aluminium-containing nanoparticles were detected by spICP-MS in all 21 samples. Depending on the assumed particle composition, $\mathrm{Al}_{2} \mathrm{O}_{3}$ or $\mathrm{Al}_{2} \mathrm{O}_{3} \cdot 2 \mathrm{SiO}_{2} \cdot 2 \mathrm{H}_{2} \mathrm{O}$, the median particle diameters were either below or above $100 \mathrm{~nm}$, respectively. The minimum detectable particle diameter by spICP-MS was between 54 and $83 \mathrm{~nm}$. The mass recovery of aluminium in the form of particles was between 5 and $18 \%$. The presented work reports for the first time the detection of Al-containing particles in food by spICP-MS.
\end{abstract}

Keywords: aluminium, acid digestion, enzymatic digestion, food labelling, nanomaterials, nanoparticles, single particle ICP-MS

\section{Introduction}

Many diverse opportunities for nanotechnology exist in the food, feed and agricultural sector (Imran et al. 2010; Singh Sekhon 2014; Greiner et al. 2015; Belluco et al. 2016; Chen et al. 2016). Currently, food contact materials and food additives are the dominating applications of nanomaterials (R. Peters et al. 2014). As a consequence of this, different approaches have been taken in regulating nano-based products (Amenta et al. 2015) including labelling for the content of nanomaterials (as ingredients) in food, which is mandatory in the European Union (EU) since December 2014 (The European Parliament and the Council of the European Union 2011). All ingredients present in the form of engineered nanomaterials have to be clearly indicated in the list of ingredients with the names of such ingredients followed by the word 'nano' 
in brackets. Foods modified by nanotechnology and nanoscience as well as food, vitamins, minerals and other substances containing or consisting of engineered nanomaterials are covered by the 'Novel foods regulation' (The European Parliament and the Council of the European Union 2015). According to the European Commission's (EC) recommendation on the definition of nanomaterial from 2011, a nanomaterial is defined as 'a natural, incidental or manufactured material containing particles, in an unbound state or as an aggregate or as an agglomerate and where, for $50 \%$ or more of the particles in the number size distribution, one or more external dimensions is in the size range $1 \mathrm{~nm}-100 \mathrm{~nm}$ '. A particle is defined as 'a minute piece of matter with defined physical boundaries' (The European Commission 2011). This recommendation is currently under review with the goal to identify issues encountered since its adoption and a possible revision of the definition as a result of the review (Rauscher et al. 2017). The EC intends to amend the sector-specific regulatory definitions of nanomaterials valid for foodstuff by harmonizing it with the EC's recommendation, while still taking into account sector-specific needs (Rauscher et al. 2017).

In the context of these regulations and for risk assessment purposes, analytical methods for identifying nanomaterials (according to the EU definition) and for assessing whether or not a product contains nanomaterials are urgently required (Stamm et al. 2012; Mattarozzi et al. 2017). Several (review) papers have highlighted the challenges of analysing nanomaterials in food (Stamm et al. 2012; Szakal et al. 2014; Singh et al. 2014; Picó 2016; Mattarozzi et al. 2017). Among the currently most widespread techniques for the detection and characterization of nanoparticles (NPs) in food, inductively coupled plasma-mass spectrometry (ICP-MS) used in single particle mode (spICP-MS) appears to be closest to a routine application (Mattarozzi et al. 2017). 
This technique has been shown to be a powerful tool for nanoanalysis, which uses the well-established technique of ICP-MS on a 'particle by particle' basis (Laborda et al. 2014). The technique can distinguish between ionic and nanoparticle forms of an element and provide (number-based) particle size distribution. For spICP-MS the sample needs to be in liquid suspension. Therefore, when applied to detection of NPs in semi-solid or solid foods, suitable sample preparation procedures are necessary for liberating the NPs into liquid suspension. Currently, the applications of spICP-MS to (potential) food matrices are limited and include game meat (PbNPs) (Kollander et al. 2017), ground beef (AgNPs, AuNPs) (Gray et al. 2013), chicken meat (AgNPs) (Loeschner et al. 2013; R.J.B. Peters, Rivera, et al. 2014), garden cress (Lepidium sativum) (PtNPs) (Jiménez-Lamana et al. 2016), chewing gum $\left(\mathrm{TiO}_{2}\right)$ (R.J.B. Peters, Bemmel, et al. 2014) and pastry decoration (AgNPs) (Verleysen et al. 2015).

Aluminium (Al) is a silvery-grey, soft and nonmagnetic metal that occurs naturally in the environment ( $8 \%$ of the earth crust by mass). In addition, $\mathrm{Al}$ is released into the environment due to anthropogenic activities, such as mining and industrial uses, in the production of aluminium metal and other aluminium compounds (EFSA 2008). The major route of exposure to $\mathrm{Al}$ for the general population is through food with additional (minor) exposure arising from drinking water and the use of aluminium compounds in pharmaceuticals and consumer products (EFSA 2008). Most unprocessed foods typically contain less than $5 \mu \mathrm{g} \mathrm{Al} / \mathrm{g}$ (EFSA 2008). Higher concentrations (mean levels 5 to $10 \mu \mathrm{g} / \mathrm{g}$ ) were often found in breads, cakes and pastries (with biscuits having the highest levels) and a majority of flours (EFSA 2008). The individual $\mathrm{Al}$ compounds or species contributing to the $\mathrm{Al}$ content in particular foods were not determined. Al can be found in foods as a natural constituent taken up from soil or as a food additive. EU food additives containing Al are, e.g., metallic Al (E173; 
for decorative purposes), Al sulphates (E520-523; as firming agent / stabilizer) and Al silicates (E554/E555; as anticaking agent) (DG Sante 2017). In addition, Al lakes are used in authorised water-insoluble food colours (EFSA 2008). Depending on its source, Al can be present as ions (complexed with organic molecules) or as particulates, a fraction of which may occur at the nanometre size scale. In 2008, EFSA published a comprehensive report regarding the safety of Al from dietary intake (EFSA 2008) and established a tolerable weekly intake for $\mathrm{Al}$ of $1 \mathrm{mg} \mathrm{Al}$ per kilogram body weight per week. The EFSA Panel noted that Al-containing compounds have shown embryotoxicity in mice, have affected the developing nervous system in the offspring of mice and rats, have the potential to produce neurotoxicity (mice, rats) and to affect the male reproductive system (dogs). It was further noted that there are very few specific toxicological data for food additives containing Al.

A few years ago, increased levels of Al in imported noodles attracted the attention of national food authorities in several countries (Laboratory of the Government Chemist (LGC) 2011). Based on these observations, an increased level of official controls for imported Chinese noodles in the European Union was decided in 2010 , meaning that $10 \%$ of imported consignments should be sampled (The European Commission 2010). It has been speculated whether Al sulphates or other $\mathrm{Al}$ containing food additives in noodles gave rise to the elevated findings of $\mathrm{Al}$ in imported noodles or rather the natural concentrations of $\mathrm{Al}$ in Asian wheat flour (Laboratory of the Government Chemist (LGC) 2011).

The presence of inorganic nano- and microparticles in wheat and wheat-based products was shown in previous studies. Particles containing Fe or Ti in the size range between 1 to $10 \mu \mathrm{m}$ were detected in durum wheat seeds, wheat seeds, semolina, wheat flour, biscuits and pasta samples by scanning electron microscopy (SEM) in 
combination with energy-dispersive X-ray spectroscopy (EDS) (Beltrami et al. 2011).

Particles of other metals, like copper and zinc, were only occasionally found, but Al was not mentioned. A decrease in the concentration of Ti and Fe particles from wheat to flour and from durum wheat to semolina samples was observed, indicating an external contamination of grains by metal particles. In the finished food products, pasta (spaghetti and biscuits), the number of Fe and Ti particles was in the same order of magnitude as in some of the studied samples of wheat and wheat flours. It was concluded that the detected inorganic nano- and microparticles could be attributed mostly to natural sources or anthropomorphic combustion and, only to a minor part, to food processing. In a similar study, 86 samples of wheat bread and 49 of wheat biscuits from 14 different countries were analyzed by environmental SEM in combination with EDS (Gatti et al. 2009). 38.5\% of the samples were contaminated with inorganic particles in the size range of $100 \mathrm{~nm}$ to $100 \mu \mathrm{m}$. Also clusters of NPs were found with a maximum size of $26 \mu \mathrm{m}$. The major elements found in the particles were iron, lead, tungsten, titanium, aluminum, silicon and silver. As potential origin of the particles, industrial processing (wear of industrial tools) or the environment (where crops are grown and particle contamination occurs from incinerators, power plants, domestic heating, car traffic etc.) were listed.

Because of relatively high concentration of $\mathrm{Al}$ in Chinese noodles compared with most other foods, in combination with toxicological concern about the dietary intake of Al, a set of 21 samples of noodles were collected as part of the Danish monitoring program. The aim of the work was develop a method for analysis of Alcontaining NPs and to investigate whether the noodle samples contained nanoparticles or not. 


\section{Materials and methods}

The samples were taken as import controls by the Danish Veterinary and Food Administration with a frequency of $10 \%$. Sample-taking was performed as a result of Commission Regulation (EU) No 878/2010 amending Annex I to Regulation (EC) No 669/2009. The samples were taken in the wholesale chain of different importers.

Initially the samples were crushed in a bag with a rubber mallet. Then the samples were further ground in a Retch centrifugal mill, and from there two subsamples of 50-100 g were taken and transferred to plastic bags. Based on the ingredient list, none of the samples contained food additives based on aluminium-containing compounds. A total of 21 samples of imported Chinese noodles were studied.

The total Al content of the noodle samples was determined by conventional ICPMS using two sample preparation methods and based on standard procedures for metals in food (European Committee for Standardization 2010; European Committee for Standardization 2014): a) microwave-assisted acid digestion by nitric acid $\left(\mathrm{HNO}_{3}\right)$, and b) acid digestion by a mixture of nitric acid, hydrogen peroxide $\left(\mathrm{H}_{2} \mathrm{O}_{2}\right)$ and hydrofluoric acid.

For investigating the presence of Al-containing particles by spICP-MS, samples were prepared using microwave-assisted acid digestion $\left(\mathrm{HNO}_{3}+\right.$ hydrogen peroxide $\mathrm{H}_{2} \mathrm{O}_{2}$ ) and additionally enzymatic digestion. Enzymatic digestion with $\alpha$-amylase (30 U/mg, from Aspergillus oryzae, Sigma Aldrich product number 10065) was applied by modifying the protocol of Beltrami et al. Briefly, $0.03 \mathrm{~g}$ of sample were mixed with 10 $\mathrm{mL}$ of $40 \mathrm{mM}$ TRIS buffer and $0.03 \mathrm{~g}$ of $\alpha$-amylase. A test portion of $0.1 \mathrm{~g}$ led to incomplete digestion. As a sample preparation blank, the same mixture but without added sample was prepared. The Standard Reference Material (SRM) 1567a Wheat Flour from the National Institute of Standards and Technology (NIST, Gaithersburg, MD, USA) was included in the analysis and prepared in the same way as the samples. 
The certified Al concentration was $5.7 \pm 1.3 \mu \mathrm{g} / \mathrm{g}$ dry weight. The ICP-MS results after total digestion with $\mathrm{HF}(5.7 \pm 0.3 \mu / \mathrm{g}, \mathrm{N}=2)$ were in good agreement with the certified value.

The mixture was incubated at $40^{\circ} \mathrm{C}$ in a water bath using continuous stirring overnight. Samples were diluted 30-times with ultrapure water prior to analysis. This dilution factor assured that at least 1000 particles were detected during one acquisition. At the same time, the number of readings/data points with particle events was limited to $5 \%$ to keep the contribution of multiple particle events (more than one particle reaching the plasma during the dwell time of $3 \mathrm{~ms}$ ) to the size distribution below $3 \%$ according to Poisson statistics.

An iCAP Q ICP-MS instrument (Thermo Fisher Scientific GmbH, Bremen, Germany) was used for all spICP-MS experiments. Instrument tuning was performed prior to analysis by using a tuning solution according to the manufacturer's recommendation. Instrument settings are given in Table 1.

[Table 1 near here]

Data processing was performed as described previously (Loeschner et al. 2015). The peristaltic pump of the inlet system of the ICP-MS was set to 40 rounds per minute for all experiments, which corresponded to a sample flow rate of approximately 0.4 $\mathrm{mL} / \mathrm{min}$, which was accurately determined daily by weighing using pure water at room temperature as sample. A calibration curve was constructed by analysis of an acid blank solution and five $\mathrm{Al}$ standards ranging from 0.2 to $5.0 \mathrm{ng} / \mathrm{L}$ diluted in ultrapure water prepared from a certified solution. The ${ }^{27} \mathrm{Al}$ intensity for each solution was then averaged from the entire length of the analysis $(60 \mathrm{~s})$. The transport efficiency of the liquid samples through the sample introduction system was determined by measuring a NIST gold NP suspension with an average particle diameter of $56.0 \mathrm{~nm}$ (based on 
measurements by transmission electron microscopy provided by NIST) and a gold mass concentration of $51.86 \pm 0.64 \mu \mathrm{g} / \mathrm{g}$ (information value provided by NIST), diluted $10^{6}$ times with ultrapure water. The transport efficiency was calculated as the percentage of all Au nanoparticles detected by spICP-MS versus the theoretical (calculated) particle number.

For each sample the ${ }^{27} \mathrm{Al}$ signal intensity was recorded for $180 \mathrm{~s}$ using a dwell time of $3 \mathrm{~ms}$, which corresponded to 60,000 recorded data points. Following the analysis of each sample, ultrapure water was analysed for $60 \mathrm{~s}$ to illustrate if carry-over from the previous measurement could be excluded. For all analyses, the recorded signal intensity data were plotted (in cps) versus number of 'events', to create a signal distribution. The low, stable and relatively noise-free signal intensities were considered to be caused by instrument background and polyatomic interferences or, for slightly higher intensity values, also caused by dissolved $\mathrm{Al}$ (ions and molecules) in the sample. An iterative algorithm was applied where particle events were distinguished as outliers from the polyatomic background and dissolved metal signal if the measured intensity was more than five times the standard deviation of the whole data set. This criterion ensured that only NPs and no instrumental background signal or signal from Al ions or molecules were included in the dataset. Particle size histograms were plotted using OriginPro 2016 (OriginLab Corporation, MA, USA). For the calculation of particle diameter from particle mass, we assumed a spherical shape of the particle and considered two potential compositions: $\mathrm{Al}_{2} \mathrm{O}_{3}$ and $\mathrm{Al}_{2} \mathrm{Si}_{2} \mathrm{O}_{5}(\mathrm{OH})_{4}\left(\mathrm{Al}_{2} \mathrm{O}_{3} \cdot 2 \mathrm{SiO}_{2} \cdot 2 \mathrm{H}_{2} \mathrm{O}\right)$. Particle densities of 3.97 and $2.61 \mathrm{~g} / \mathrm{cm}^{3}$, respectively, were used for the calculations assuming similar densities as the bulk material. Results are in general presented as mean \pm 1 standard deviation. 


\section{Results and discussion}

The Al concentrations determined without or with the use of HF for digestion were $5.4 \pm 1.9 \mu \mathrm{g} / \mathrm{g}$ and $10.1 \pm 2.2 \mu \mathrm{g} / \mathrm{g}(\mathrm{N}=21)$, respectively. In 11 of the 21 samples, the $\mathrm{Al}$ concentration exceeded $10 \mu \mathrm{g} \mathrm{Al} / \mathrm{g}$ dry sample after $\mathrm{HF}$ digestion, which is the current recommended EU limit. The consistently higher (about 2-fold) concentrations obtained after using HF suggested that some of the Al in the noodles was present as compounds which are only soluble in HF, such as aluminium silicate, which could be present in particulate form.

spICP-MS analysis demonstrated the presence of Al-containing particles after both sample preparation procedures, acid digestion $\left(\mathrm{HNO}_{3}+\mathrm{H}_{2} \mathrm{O}_{2}\right)$ and enzymatic digestion, although at a much larger number concentration following enzymatic digestion (Figure 1). Consequently, enzymatic digestion was chosen as a sample preparation method for spICP-MS of the 21 noodle samples.

[Figure $1 \mathrm{a}+\mathrm{b}$ near here]

After enzymatic digestion, the number of detected particles during one acquisition (180 s) was in the range of 1527 to 2668 particles. Mass recoveries of $\mathrm{Al}$ in the form of particles were $12.2 \%$ in comparison to Al concentrations determined in HFdigested samples, indicating that a large fraction of $\mathrm{Al}$ in the samples was either not present as NPs or NPs below/above the detectable particle size range. Particle diameters were calculated for two possible compositions, $\mathrm{Al}_{2} \mathrm{O}_{3}$ or $\mathrm{Al}_{2} \mathrm{O}_{3} \cdot 2 \mathrm{SiO}_{2} \cdot 2 \mathrm{H}_{2} \mathrm{O}$, to illustrate the influence of the (assumed) particle composition on the determined size distributions (Figure 2). Commonly used Al compounds, which are water insoluble or poorly soluble, include $\mathrm{Al}$ hydroxide, $\mathrm{Al}$ oxide $\left(\mathrm{Al}_{2} \mathrm{O}_{3}\right.$, selected possible composition 1), Al phosphate, calcium Al silicate (E556), Al silicate / kaolin (E559, $\mathrm{Al}_{2} \mathrm{O}_{3} \cdot 2 \mathrm{SiO}_{2} \cdot 2 \mathrm{H}_{2} \mathrm{O}$, selected possible composition 2), sodium Al silicate (E554), potassium Al silicate / natural mica (E555), acidic sodium Al phosphate (E541) (EFSA 2008). Only the last three are 
authorized food additives in the EU. As the shape of the NPs was unknown, spherical particles were assumed, which is currently the common assumption in spICP-MS measurements (Mattarozzi et al. 2017).

The number-based size distributions, which were obtained for the case of $\mathrm{Al}_{2} \mathrm{O}_{3}$ NPs in the enzymatically digested samples $(\mathrm{N}=21)$, had diameters ranging from $68 \pm 7$ $\mathrm{nm}$ (corresponding to the lower size limit of detection) up to $595 \pm 90 \mathrm{~nm}$ with median diameters of $86 \pm 8 \mathrm{~nm}$ (Figure 2 and Table 2). With decreasing particle mass density and decreasing molar fraction of the analyte in the particle, the particle sizes increase (e.g. by a factor or $1.57 \mathrm{in}$ the case of $\mathrm{Al}_{2} \mathrm{O}_{3} \cdot 2 \mathrm{SiO}_{2} \cdot 2 \mathrm{H}_{2} \mathrm{O}$ NPs). Depending on the selected particle composition, the median particle diameters were either below $\left(\mathrm{Al}_{2} \mathrm{O}_{3}\right)$ or above $100 \mathrm{~nm}\left(\mathrm{Al}_{2} \mathrm{O}_{3} \cdot 2 \mathrm{SiO}_{2} \cdot 2 \mathrm{H}_{2} \mathrm{O}\right.$ NPs $)$. Following the $\mathrm{EC}$ 's recommendation for the definition of a nanomaterial, this would mean presence or absence of a nanomaterial in the food sample, respectively.

The finding of relatively large particles, i.e. particles of several $100 \mathrm{~nm}$, could explain to some extent the observed low $\mathrm{Al}$ mass recoveries. It should be mentioned that these large 'particles' can also be aggregates of smaller NPs. Large particles/aggregates can settle during sample preparation/analysis. They contain a large mass but their number is very low, and the likelihood of detecting such a large 'particle' during a measurement is low. Additionally, at high particle sizes / masses incomplete particle vaporization and non-linear detector responses can occur leading to an underestimation of particle size and mass (Lee \& Chan 2015).

[Figure 2 near here]

In the sample preparation blanks, around 140 NPs with median diameters of 61 to $74 \mathrm{~nm}$ were detected during the analysis time of $180 \mathrm{~s}$. The finding of NPs in the sample preparation blanks suggests some carry-over of NPs from previous analyses or 
formation of NPs in the sample introduction system from remaining Al ions. As the minimum detected number of NPs in the samples (same dilution factor) was 1527, the influence of carry-over can be considered negligible. The LOD for the mass concentration of the 'Al background' (ionic Al, other Al species and Al-containing NPs below the minimum detectable size) was calculated to be $2.7 \mu \mathrm{g} / \mathrm{g}$ ( 3 times the standard deviation of sample preparation blank; $\mathrm{N}=2$ ). The LOD was slightly exceeded for three samples $(2.8,3.1,3.5 \mu \mathrm{g} / \mathrm{g})$.

Interestingly, a significant number of NPs (1774 \pm 59 during $180 \mathrm{~s} ; \mathrm{N}=2)$ was detected in the SRM Wheat Flour. This supports the suggestion that Al findings in noodles are caused by the natural concentrations of Al in wheat flour (Laboratory of the Government Chemist (LGC) 2011). The presence of inorganic nano- and microparticles in wheat and wheat-based products was shown in previous studies but not for the case of Al (Gatti et al. 2009; Beltrami et al. 2011).

[Table 2 near here]

\section{Summary and conclusions}

To the best of our knowledge, this is the first study that shows the potential presence of Al-containing nanoparticles in a food product by spICP-MS. Further, our study demonstrated that it is relatively simple to detect NPs in a food sample by spICPMS and that it is possible to obtain reproducible results for particle mass concentration and particle size. However, accuracy of the results could not be evaluated due to the lack of suitable reference materials. Several assumptions had to be made to convert the obtained particle mass into particle size, including assumptions for particle composition, shape and density. It was shown that these assumptions can be decisive when evaluating whether a sample contains a nanomaterial or not. The lower limit of size detection (i.e. the smallest detectable size) was another clear limitation of the spICP-MS method. For 
the presented case of Al-containing NPs, the minimum detectable particle size by conventional (quadrupole-based ICP-MS) was, depending on the particle composition, in the range of 50-60 $\mathrm{nm}$. The presence of large particles or NP aggregates challenged the upper size limit of spICP-MS.

Even if the found Al-containing particles could be categorized as a nanomaterial, it remained unclear whether the particles were intentionally added to the noodles as a food additive (and not listed on the ingredient list), whether they were the result of contamination during food processing or storage or whether the particles originated from a natural source. This poses a big challenge when investigating the proper labelling of food containing nanomaterials as ingredients. Future work needs to study the shape and chemical composition of the detected NPs by additional methods like field flow fractionation or transmission electron microscopy in combination with energy-dispersive X-Ray spectroscopy.

Acknowledgements

We thank Erik H. Larsen and Marianne Hansen for their assistance in planning and performing the work. This work was supported by University of Granada and CEIBiotic under the $\mathrm{PhD}$ international mobility programme

\section{References:}

Amenta V, Aschberger K, Arena M, Bouwmeester H, Botelho Moniz F, Brandhoff P, Gottardo S, Marvin HJP, Mech A, Quiros Pesudo L, et al. 2015. Regulatory aspects of nanotechnology in the agri/feed/food sector in EU and non-EU countries. Regul Toxicol Pharmacol [Internet]. 73:463-476. Available from: http://dx.doi.org/10.1016/j.yrtph.2015.06.016

Belluco S, Gallocchio F, Losasso C, Ricci A. 2016. State of art of nanotechnology applications in the meat chain: a qualitative synthesis. Crit Rev Food Sci Nutr 
[Internet]. [cited 2016 Oct 31]:1-13. Available from:

https://www.tandfonline.com/doi/full/10.1080/10408398.2016.1237468

Beltrami D, Calestani D, Maffini M, Suman M, Melegari B, Zappettini A, Zanotti L,

Casellato U, Careri M, Mangia A. 2011. Development of a combined SEM and

ICP-MS approach for the qualitative and quantitative analyses of metal

microparticles and sub-microparticles in food products. Anal Bioanal Chem

[Internet]. [cited 2013 Nov 26]; 401:1401-9. Available from:

http://www.ncbi.nlm.nih.gov/pubmed/21660413

Chen T, Zhang M, Bhandari B, Yang Z. 2016. Micronisation and Nanosizing of particles for an Enhanced Quality of Food: a Review. Crit Rev Food Sci Nutr [Internet]. [cited 2016 Oct 31]:00-00. Available from:

https://www.tandfonline.com/doi/full/10.1080/10408398.2016.1236238

Degueldre C, Favarger P-Y. 2003. Colloid analysis by single particle inductively coupled plasma-mass spectroscopy: a feasibility study. Colloids Surfaces A Physicochem Eng Asp [Internet]. [cited 2013 Nov 12]; 217:137-142. Available from: http://linkinghub.elsevier.com/retrieve/pii/S092777570200568X

DG Sante. 2017. Database on Food Additives [Internet]. [cited 2017 May 31]. Available from:

https://webgate.ec.europa.eu/foods_system/main/?sector=FAD\&auth=SANCAS

EFSA. 2008. Scientific Opinion of the Panel on Food Additives, Flavourings,

Processing Aids and Food Contact Materials on a request from European

Commission on Safety of aluminium from dietary intake. EFSA J. 754:1-34.

European Committee for Standardization. 2010. Foodstuffs - Determination of trace elements - Determination of arsenic, cadmium, mercury and lead in foodstuffs by inductively coupled plasma mass spectrometry (ICP-MS) after pressure digestion (EN 15763). :18.

European Committee for Standardization. 2014. Foodstuffs - Determination of trace elements - Pressure digestion (EN 13805:2014). :12.

Gatti AM, Tossini D, Gambarelli A, Montanari S, Capitani F. 2009. Investigation of the presence of inorganic micro- and nanosized contaminants in bread and biscuits by environmental scanning electron microscopy. Crit Rev Food Sci Nutr [Internet]. [cited 2013 Nov 26]; 49:275-82. Available from: http://www.tandfonline.com/doi/abs/10.1080/10408390802064347 
Gray EP, Coleman JG, Bednar AJ, Kennedy AJ, Ranville JF, Higgins CP. 2013.

Extraction and analysis of silver and gold nanoparticles from biological tissues using single particle inductively coupled plasma mass spectrometry. Environ Sci Technol [Internet]. 47:14315-23. Available from: http://www.ncbi.nlm.nih.gov/pubmed/24218983

Greiner R, Gräf V, Burcza A, Hetzer B, Milsmann J, Walz E. 2015. Engineered Nanomaterials in the Food Sector. [place unknown]: Elsevier. Available from: http://linkinghub.elsevier.com/retrieve/pii/B978044463340800011X

Imran M, Revol-Junelles A-M, Martyn A, Tehrany EA, Jacquot M, Linder M, Desobry S. 2010. Active Food Packaging Evolution: Transformation from Micro- to Nanotechnology. Crit Rev Food Sci Nutr [Internet]. [cited 2016 Oct 31]; 50:799-821. Available from:

http://www.tandfonline.com/doi/abs/10.1080/10408398.2010.503694

Jiménez-Lamana J, Wojcieszek J, Jakubiak M, Asztemborska M, Szpunar J. 2016. Single particle ICP-MS characterization of platinum nanoparticles uptake and bioaccumulation by Lepidium sativum and Sinapis alba plants. J Anal At Spectrom [Internet]. [cited 2017 Jan 27]; 31:2321-2329. Available from: http://pubs.rsc.org/en/Content/ArticleLanding/2016/JA/C6JA00201C

Kollander B, Widemo F, Ågren E, Larsen EH, Loeschner K. 2017. Detection of lead nanoparticles in game meat by single particle ICP-MS following use of leadcontaining bullets. Anal Bioanal Chem [Internet]. 409:1877-1885. Available from: http://link.springer.com/10.1007/s00216-016-0132-6

Laboratory of the Government Chemist (LGC). 2011. Independent report Aluminium in imported noodles: recommendations for analysis. Suppl Expert Opin case [Internet]. [cited 2017 Jun 8]:1-7. Available from:

https://www.gov.uk/government/publications/aluminium-in-imported-noodlesrecommendations-for-analysis

Laborda F, Bolea E, Jimenez-Lamana J. 2014. Single Particle Inductively Coupled Plasma Mass Spectrometry: A Powerful Tool for Nanoanalysis. Anal Chem. 86:2270-2278.

Lee W-W, Chan W-T. 2015. Calibration of single-particle inductively coupled plasmamass spectrometry (SP-ICP-MS). J Anal At Spectrom [Internet]. 30:1245-1254. Available from: http://xlink.rsc.org/?DOI=C4JA00408F 
Loeschner K, Harrington CFCF, Kearney J-LJ-L, Langton DJDJ, Larsen EHEH. 2015. Feasibility of asymmetric flow field-flow fractionation coupled to ICP-MS for the characterization of wear metal particles and metalloproteins in biofluids from hip replacement patients. Anal Bioanal Chem [Internet]. 407:4541-4554. Available from: http://link.springer.com/10.1007/s00216-015-8631-4

Loeschner K, Navratilova J, Købler C, Mølhave K, Wagner S, Von Der Kammer F, Larsen EH. 2013. Detection and characterization of silver nanoparticles in chicken meat by asymmetric flow field flow fractionation with detection by conventional or single particle ICP-MS. Anal Bioanal Chem. 405:8185-8195.

Mattarozzi M, Suman M, Cascio C, Calestani D, Weigel S, Undas A, Peters R. 2017. Analytical approaches for the characterization and quantification of nanoparticles in food and beverages. Anal Bioanal Chem [Internet]. 409:63-80. Available from: http://dx.doi.org/10.1007/s00216-016-9946-5

Peters R, Brandhoff P, Weigel S, Marvin H, Bouwmeester H, Aschberger K, Rauscher H, Amenta V, Arena M, Botelho Moniz F, et al. 2014. Inventory of Nanotechnology applications in the agricultural, feed and food sector. EFSA Support Publ [Internet]. [cited 2017 May 31]; 11. Available from: http://doi.wiley.com/10.2903/sp.efsa.2014.EN-621

Peters RJB, Bemmel G Van, Herrera-rivera Z, Helsper JPFG, Hans JP, Weigel S, Tromp P, Oomen AG, Rietveld A, Bouwmeester H. 2014. Characterization of titanium dioxide nanoparticles in food products : Analytical methods to define nanoparticles. J Agric Food Chem. 62:6285-6293.

Peters RJB, Rivera ZH, Van Bemmel G, Marvin HJP, Weigel S, Bouwmeester H. 2014. Development and validation of single particle ICP-MS for sizing and quantitative determination of nano-silver in chicken meat. Anal Bioanal Chem. 406:3875-3885.

Picó Y.2016. Challenges in the determination of engineered nanomaterials in foods.

TrAC Trends Anal Chem [Internet]. Available from: http://linkinghub.elsevier.com/retrieve/pii/S0165993616301315

Rauscher H, Rasmussen K, Sokull-Klüttgen B. 2017. Regulatory Aspects of Nanomaterials in the EU. Chemie Ing Tech [Internet]. [cited 2017 Jun 6]; 89:224-231. Available from: http://doi.wiley.com/10.1002/cite.201600076 Singh G, Stephan C, Westerhoff P, Carlander D, Duncan T V. 2014. Measurement Methods to Detect, Characterize, and Quantify Engineered Nanomaterials in 
Foods. Compr Rev Food Sci Food Saf [Internet]. [cited 2015 Aug 21]; 13:693704. Available from: http://doi.wiley.com/10.1111/1541-4337.12078

Singh Sekhon B. 2014. Nanotechnology in agri-food production: An overview. Nanotechnol Sci Appl. 7:31-53.

Stamm H, Gibson N, Anklam E. 2012. Detection of nanomaterials in food and consumer products : bridging the gap from legislation to enforcement. Food Addit Contam Part A. 29:1175-1182.

Szakal C, Roberts SM, Westerhoff P, Bartholomaeus A, Buck N, Illuminato I, Canady R, Rogers M. 2014. Measurement of nanomaterials in foods: integrative consideration of challenges and future prospects. ACS Nano [Internet]. [cited 2015 May 9]; 8:3128-35. Available from: http://dx.doi.org/10.1021/nn501108g The European Commission. 2010. Commission Regulation (EU) No 878/2010 of 6 October 2010 amending Annex I to Regulation (EC) No 669/2009 implementing Regulation (EC) No 882/2004 of the European Parliament and of the Council as regards the increased level of official controls on imports. Off J Eur Union. L 261:1-6.

The European Commission. 2011. Commission recommendation of 18 October 2011 on the definition of nanomaterial (2011/696/EU). Off J Eur Union. L275:38-40.

The European Parliament and the Council of the European Union. 2011. Regulation (EU) No 1169/2011 of the European Parliament and of the Council of 25 October 2011 on the provision of food information to consumers, amending Regulations (EC) No 1924/2006 and (EC) No 1925/2006 of the European Parliament and of the Council, a. Off J Eur Union. L 304:18-63.

The European Parliament and the Council of the European Union. 2015. Regulation (Eu) 2015/2283 of the European Parliament and of the Council of 25 November 2015 on novel foods, amending Regulation (EU) No 1169/2011 of the European Parliament and of the Council and repealing Regulation (EC) No 258/97 of the European Parliam. Off J Eur Union. L 327:1-22.

Verleysen E, Van Doren E, Waegeneers N, De Temmerman PJ, Abi Daoud Francisco M, Mast J. 2015. TEM and SP-ICP-MS Analysis of the Release of Silver Nanoparticles from Decoration of Pastry. J Agric Food Chem. 63:3570-3578. 
Table 1. spICP-MS settings

\begin{tabular}{ll}
\hline Parameter (unit) & Value \\
RF power $(\mathrm{W})$ & 1,550 \\
Plasma gas flow rate $(\mathrm{L} / \mathrm{min})$ & 13.9 \\
Nebulizer gas flow rate $(\mathrm{mL} / \mathrm{min})$ & 1.07 \\
Auxiliary gas flow rate $(\mathrm{mL} / \mathrm{min})$ & 0.79 \\
Cell gas (flow rate) $(\mathrm{mL} / \mathrm{min})$ & $\mathrm{n} / \mathrm{a}$ \\
Sample uptake flow rate $(\mathrm{mL} / \mathrm{min})$ & $\sim 0.3^{\mathrm{a}}$ \\
Monitored isotopes $(\mathrm{m} / \mathrm{z})$ & ${ }^{27} \mathrm{Al},{ }^{197} \mathrm{Au}^{\mathrm{b}}$ \\
Dwell time $(\mathrm{ms})$ & 3 \\
Analysis time $(\mathrm{s})$ & $60-180$ \\
Nebulizer type & Low-flow concentric nebulizer \\
Spray chamber type & Cyclonic, Peltier-cooled \\
\hline${ }^{\mathrm{a}}$ Determined on a daily basis (corresponding peristaltic pump speed was 40 rounds $\left./ \mathrm{min}\right)$ \\
${ }^{\mathrm{b}}$ For determination of transport efficiency
\end{tabular}


Table 2. Results of the spICP-MS analysis of enzymatically digested noodle samples $(\mathrm{N}=21)$ assuming $\mathrm{Al}_{2} \mathrm{O}_{3}$ NPs. The relative standard deviation (RSD) of repeatability was determined as the pooled RSD from seven double determinations. For $\mathrm{Al}_{2} \mathrm{O}_{3} \cdot 2 \mathrm{SiO}_{2} \cdot 2 \mathrm{H}_{2} \mathrm{O}$ NPs particle diameters are larger by a factor of 1.57 and particle mass concentrations larger by a factor of 2.53 (recovery of $\mathrm{Al}$ in particles remains the same).

\begin{tabular}{|c|c|c|c|c|c|}
\hline & $\begin{array}{l}\text { Minimum } \\
\text { detectable } \\
\text { particle } \\
\text { diameter } \\
(\mathrm{nm})\end{array}$ & $\begin{array}{l}\text { Median } \\
\text { particle } \\
\text { diameter } \\
(\mathrm{nm})\end{array}$ & $\begin{array}{l}\text { Maximum } \\
\text { particle } \\
\text { diameter } \\
(\mathrm{nm})\end{array}$ & $\begin{array}{l}\text { Particle mass } \\
\text { concentration } \\
\left(\mu \mathrm{g} \mathrm{Al}_{2} \mathrm{O}_{3} \text { per }\right. \\
\mathrm{g} \text { sample) }\end{array}$ & $\begin{array}{l}\text { of } \mathrm{Al} \text { in } \\
\text { particles } \\
\text { in } \\
\text { relation } \\
\text { to HF } \\
\text { digestion } \\
(\%)^{*}\end{array}$ \\
\hline \multicolumn{6}{|l|}{ Noodlesamples $(\mathrm{N}=21)$} \\
\hline Minimum & 54 & 70 & 443 & 0.9 & 5.3 \\
\hline Maximum & 83 & 105 & 739 & 4.3 & 18.4 \\
\hline Mean & 68 & 86 & 595 & 2.4 & 12.2 \\
\hline Standard deviation & 7 & 8 & 90 & 0.8 & 3.3 \\
\hline Repeatability RSD & $1.8 \%$ & $2.7 \%$ & $33.5 \%$ & $10.8 \%$ & - \\
\hline \multicolumn{6}{|l|}{ SRM $(\mathrm{N}=2)$} \\
\hline Mean & 62 & 78 & 788 & 1.5 & 36.1 \\
\hline Standard deviation & 1 & 3 & 138 & 0.3 & 19.9 \\
\hline
\end{tabular}

* Or certified Al concentration in the SRM 
Figure 1a: Time resolved spICP-MS signal for $\mathrm{m} / \mathrm{z} 27$ for a noodle sample after acid digestion with $\mathrm{HNO}<\mathrm{sub}>3</$ sub $>$ (a) and after enzymatic digestion with ?amylase (b)

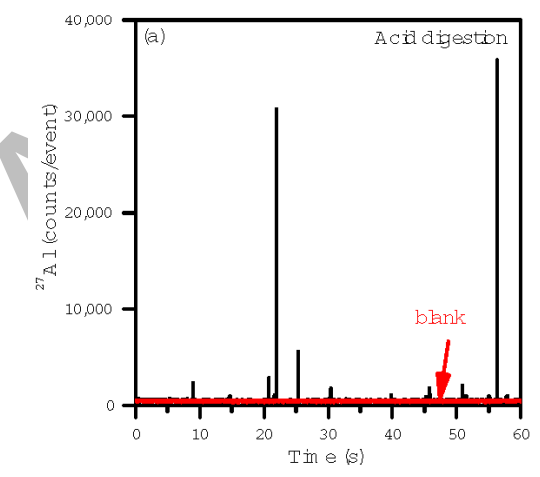


Figure 1b: Time resolved spICP-MS signal for $\mathrm{m} / \mathrm{z} 27$ for a noodle sample after acid digestion with $\mathrm{HNO}<\mathrm{sub}>3</$ sub $>$ (a) and after enzymatic digestion with ?amylase (b)

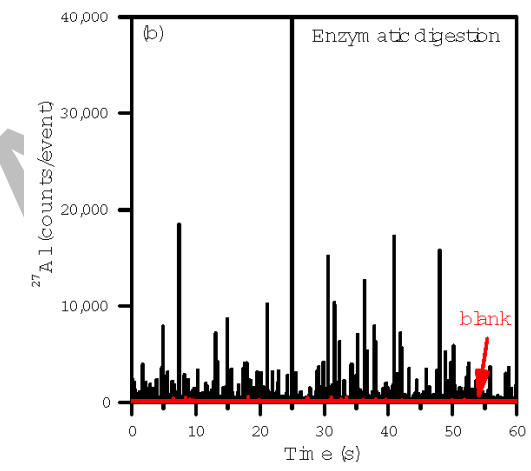


Figure 2: Number-based particle size distribution for one noodle sample after enzymatic digestion assuming spherical $\mathrm{Al}<\mathrm{sub}>2</$ sub $>\mathrm{O}<\mathrm{sub}>3</$ sub $>$ particles or $\mathrm{Al}<$ sub $>2</$ sub $>0<$ sub $>3</$ sub $>$ ? $2 \mathrm{SiO}<$ sub $>2</$ sub $>$ ?2 $\mathrm{H}<$ sub $>2</$ sub $>\mathrm{O}$ particles

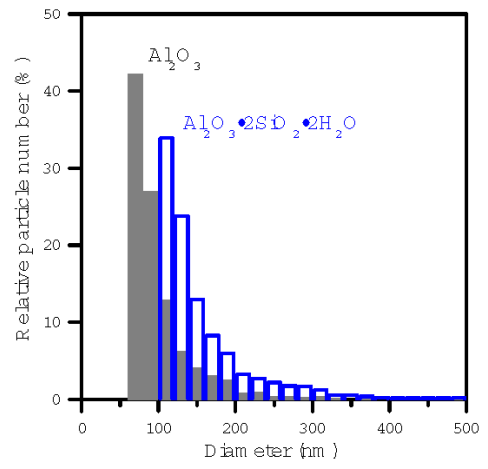

